\title{
SLAMF1 Gene
}

National Cancer Institute

\section{Source}

National Cancer Institute. SLAMF1 Gene. NCI Thesaurus. Code C104059.

This gene is involved in immune cell function. 